\title{
Biodiversity and Human Livelihoods in Protected Areas: Worldwide Perspective-A Review
}

\author{
Zewde Achiso* \\ Lecturer, Department of Biology, Wolaita Sodo University, Sodo, Ethiopia
}

*Address for Correspondence: Mr. Zewde Achiso, Lecturer, Department of Biology, Wolaita Sodo University, Sodo, Ethiopia

E-mail: zewde achiso@yahoo.com; Fax Number: +251465515113

Received: 28 Dec 2019/ Revised: 26 Mar 2020/ Accepted: 28 Apr 2020

\begin{abstract}
The overall aim of this paper was to review and compile information on protected areas for biodiversity and human livelihoods from a worldwide perspective. Globally, the biosphere is suffering unprecedented degradation of ecosystem and biodiversity loss; about $60 \%$ of the ecosystem services are unsustainable and gradually declining. The pace of wild species extinction, increased extremely. People have altered ecosystems in profound ways, including land-cover and land-use change the spread of invasive species, climate disruption and pollution. An approach that is supposed to curb such threats is the protected areas (PAs). Building PAs remains one of the most successful strategies for biodiversity conservation and regarded as the milestone scale on earth. World widely, the coverage of PAs has increased from 13.4 million square kilometers in 1990 to 32 million square kilometers in 2014 , with a total of 209,000 PAs that cover $15.4 \%$ of the world's terrestrial surface and $3.4 \%$ of the ocean areas. As natural ecosystems shrink and fragment in many parts of the world, protected areas are expected to fulfil the needs, primarily around protecting natural capital. In the past few decades, remarkable amount of protected reserve forest and wildlife sanctuary all over the world has brought and protected under different IUCN management categories and the report of 2018 IUCN shows there is positive progress, but nearly half of these are heavily used illegally for agriculture, forest product extraction and illegal hunting of wild animals, which shows that the need of strategic tackling of direct and indirect threats of PAs.
\end{abstract}

Key-words: Biodiversity, Ecological protection, Fragment, Protected areas, Species extinction, Wild life sanctuary

\section{INTRODUCTION}

In the past 50 years, natural resources on Earth have provided around 15 trillion pounds of natural products. However, human activities have destroyed $2 / 3$ of the environment that supports these resources. Moreover, about $60 \%$ of the ecosystem services are unsustainable and gradually declining. The pace of species extinction, increased extremely ${ }^{[1]}$. Since the Cenozoic era, extensive species extinction imposed Global biosphere ${ }^{[2]}$. Ecosystems were altered due to land-use and land-cover change, spread of invasive species, pollution and climate change, which reduced biodiversity and ecosystem services ${ }^{[3]}$.

\section{How to cite this article}

Achiso Z. Biodiversity and Human Livelihoods in Protected Areas: Worldwide Perspective-A Review. SSR Inst. Int. J. Life Sci., 2020; 6(3): 2565-2578.

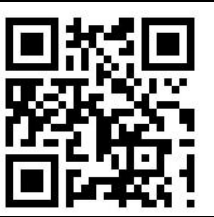

Changes occurring because of human beings continue to threaten natural ecosystems and biodiversity extensively ${ }^{[4]}$. A central approach to curb such threats is establishing PAs, which is geographical space, recognized and managed through legal means to achieve the long-term conservation of nature with the associated ecosystem services and cultural values ${ }^{[5]}$. It is also the policy instrument for the preservation and sustainable use of natural resources ${ }^{[6]}$; vital tool for sustainable development ${ }^{[5]}$ and to enhance positive expectation in protected areas.

Historically, throughout the world, societies set aside land from its conventional uses to protect particular natural or cultural values ${ }^{[7]}$. In this way, hilltops, oldgrowth forests and seashores maintained their biodiversity and scenic attributes. Currently, distribution of protected areas are guided by a complex interplay of motivations related to societal benefits ${ }^{[7]}$, significant to sustain nature. Globally, the coverage of PAs increased from 13.4 million square kilometers in 1990 to 32 million 
square kilometers in 2014, with a total of 209,000 PAs that cover $15.4 \%$ of the world's terrestrial area and $3.4 \%$ of the ocean area ${ }^{[8]}$. In the past century, the standard practice to safeguard the maintenance of biodiversity and to reduce its loss is the establishment of protected areas ${ }^{[9]}$.

Specific motivation of establishing PAs ranges from protecting areas for hunting and recreation to securing exceptional sites of geologic wonder and natural resources. Even in the case of biodiversity conservation as a goal, conflicting values can make design of PA challenging ${ }^{[10]}$. Building PAs remains one of the most successful strategies for biodiversity conservation and has been widely regarded as the milestone at various scales on earth ${ }^{[10]}$.

However, there is concern that how PAs maintain biodiversity and support livelihoods concurrently, in association with accelerated population growth and intensive land-use transformations to occur around many Pas by Joppa et al. ${ }^{[11]}$, thus promote paradigm of conservation inside PAs, but development outside of it. In contrary to this, human impacts on the surrounding lands may bleed into PAs, which decline biodiversity and create ecological degradation in it [12]. Derera [13] indicated that growth of PA in developing countries improved biodiversity conservation to human welfare from time to time. Besides, protecting an outstanding nature and recognized services provided by nature for the benefit of human being is essential, especially, in developing country where the largest part of world biodiversity is found and people's livelihood is dependent on nature.

In 1872, the U.S. established Yellowstone National Park, the first natural protected area in the world, is marked as the beginning of the modern PA. Since then, other countries in North America, Australia, and Africa established their first PA ${ }^{[5]}$. But, at the beginning of $19^{\text {th }}$ century, goals of conservation and interests of local communities were opposite to each other ${ }^{[6]}$.

Since the signing of the Convention on Biological Diversity (CBD) in 1992, many national governments around the world has agreed that creating PAs is a powerful method to cope with the destruction of biodiversity to restore fragile ecosystem and to maintain sustainable utilization of natural resources ${ }^{[15]}$. Though in 2010, the Aichi Biodiversity target proposed goal of establishing $17 \%$ terrestrial, $10 \%$ coastland marine area coverage by 2020 respectively ${ }^{[2]}$ to protect the fragile ecology of the globe, the effect of PAs couldn't be simply manifested in increase in number and coverage rather the protection efficiencies, management effects, detailed surveillance and other aspects should be accounted.

\section{Historical origins of protected areas- Different} researchers wrote many things about the creation of protected areas, the main objectives behind PA creation vary from nation to nation due to different drives in each region. The Yellowstone National Park established as the first PA in the World's in 1872 to maintain its "wilderness"[14] and this model" was applied in the establishment of PAs in countries around the World, which occasionally resulted in conflicts with local populations ${ }^{[15]}$ and the same author also indicated that in India, over 2000 years ago, royal decrees protected certain areas, in Europe, rich and powerful people protected hunting grounds for thousand years, Chinese and South Americans have decrease setting aside lands protected for plants and animals 3000 years before present.

Historically, different societies have also recognized and set aside protected areas for centuries. Sacred groves, spiritual and religious sites such as temples and burial grounds have received special recognition and respect in virtually all societies ${ }^{[16]}$. For instance, Canada's national parks system began with the establishment of Banff National Park in 1885, which is Canada's first national park typified that for many of the national parks established from the late $19^{\text {th }}$ to the later $20^{\text {th }}$ century is the Yellowstone model from the USA. Phillips ${ }^{[17]}$, briefly traces the history of protected areas in Africa. By the time in Africa, the parks were assumed as areas under strict state control, exclusively for protection, conservation, and management of vegetation and wild animals, but the public were encouraged to visit. The same report revealed that many African cultures tied to wildlife; because of wildlife in a much more real sense part of their heritage, hunting and gathering part of their everyday life. But national parks in Africa have followed the pattern of US national parks such as Yellowstone and Yosemite, where no economic activity or any hunting or fishing or gathering of wildlife is allowed.

Generally, the origins of the modern system of protected area management categories adopted by IUCN in 1994 can only be understood in the context of the history of protected areas themselves because their story is 
intermingled with that of human civilization ${ }^{[18]}$. By now, nearly every country has adopted protected area legislation and designated sites for protection. Many public, private, community and voluntary organizations are active in creating areas for protection, and many terms are used at the national level to describe Pas ${ }^{[15] .}$

Extent of protected areas currently- In response to massive biodiversity loss world widely, using the protected area as a strategy has been started in different approaches since time immemorial. The recent expansion has been closely associated with Aichi Biodiversity Target 11 , which mandates at least $17 \%$ inclusion of managed terrestrial areas effectively and ecologically representative by $2020{ }^{[7]}$. The summit held from 18 to 29 October 2010, in Nagoya, Aichi Prefecture, Japan and adopted a revised and updated strategic plan for biodiversity conservation in 2011-2020 periods. At the summit, 192 State parties were involved in CBD Aichi's Biodiversity Target 11, whose ambitious goal is managing at least $17 \%$ of terrestrial and inland water and $10 \%$ of coastal and marine areas for biodiversity and ecosystem services through effectively and equitably management approach ${ }^{[19]}$.

The protected areas coverage differs from region to region, for instances Central and South America are the two regions with the highest percentage of terrestrial and inland water protected areas $(28.2 \%$ and $25 \%$ respectively), whereas African lag behind, with a record of $14.7 \%$ of its land ${ }^{[8]}$.

The number and extent of protected areas are continually changing as areas expand, new areas are added, and sometimes also scale back for some previously protected areas ${ }^{[8]}$. An analysis of the temporal changes in protected area coverage shows that average coverage of marine PAs has continued to increase rapidly since 2016, whilst the growth in terrestrial protection has largely tapered off ${ }^{[19]}$. Forestry approaches a good tactic for biodiversity conservation and indicator to set off a protected area and fragile biodiversity in the safe side. Globally, there are various types of forests on the earth, which are vital for the conservation of biodiversity. According to FAO, the total area of forests in the world is 3.95 billion hectares in 2005 (30\% of the world' total land area) but the total forest area reported in the year 2015 was 4,000 million ha, a decrease of $3 \%$ reported in 1990 . In terms of regions, Europe, including the Russian Federation has the highest reported forest area (25\% of the total), followed by South America (21\%) and North America (16\%) ${ }^{[20]}$. The loss of 128 Million ha of global forest area from 1990 to 2015 , mainly from the tropics ${ }^{[13,17]}$ shows that global forest loss is highest in the tropical domain(area with high biodiversity) and increasing concern over forest protection. But on the contrary of this, the global coverage of PAs has been reported by ${ }^{[21]}$ in which the good progress expanding the coverage of both terrestrial and marine protected areas, with terrestrial coverage slightly increasing from $14.7 \%$ in 2016 to $14.9 \%$ in 2018 , and marine coverage increasing faster from $10.2 \%$ to $16.8 \%$ in national waters. In addition to this, the IUCN ${ }^{[21]}$ also reported that as of July 2018, there were 238,563 designated PAs recorded in the WDPA. Most areas are on land and collectively protected just over 20 million $\mathrm{km}^{2}$, equivalent to $14.9 \%$ of the earth's land surface. Marine PAs, despite being fewer in number, cover over 6 million $\mathrm{km}^{2}$ of the earth, representing $7.3 \%$ of the world's oceans, regionally ${ }^{[22]}$.

\section{Impacts of protected areas on biodiversity} conservation- Globally, varieties of ecosystems exist on the earth ranging from tropical to polar zones, and from coastal to mountainous areas, which harbor various living things. About $1,750,000$ kinds of species were already known; from these, mammals: 6,000, birds: 9,000, insects: 950,000 , and vascular plants: 270,000 . The total number of species, including unknown life on earth is $5,000,000$ to $30,000,000{ }^{[23]}$, nearly $70 \%$ of the earth's surface is covered by oceans is rich in biodiversity but under pressure due to human activities ${ }^{[25]}$. Africa is home to some one-quarter of the world's 4,700 species of mammals more than 2,000 species of birds $\left(1 / 5^{\text {th }}\right.$ of the world's total) at least 2,000species of fish, 950 amphibian species and its mainland harbors between 40,000 and 60,000 plant species and about 100,000 known species of insects. Moreover, eight of the world's 34 biodiversity hotspots are found in Africa ${ }^{\text {[21] }}$.

But natural ecosystems are in rapid decline, major habitats are disappearing at a speed never observed before and these natural gifted natural resources are on the verge of extinction. Based on this, it is predicted that 10 to $30 \%$ of known mammals, birds, and amphibian species are at the risk of extinction. For this, humans are accelerators of the species extinction rate in recent hundreds of years. 


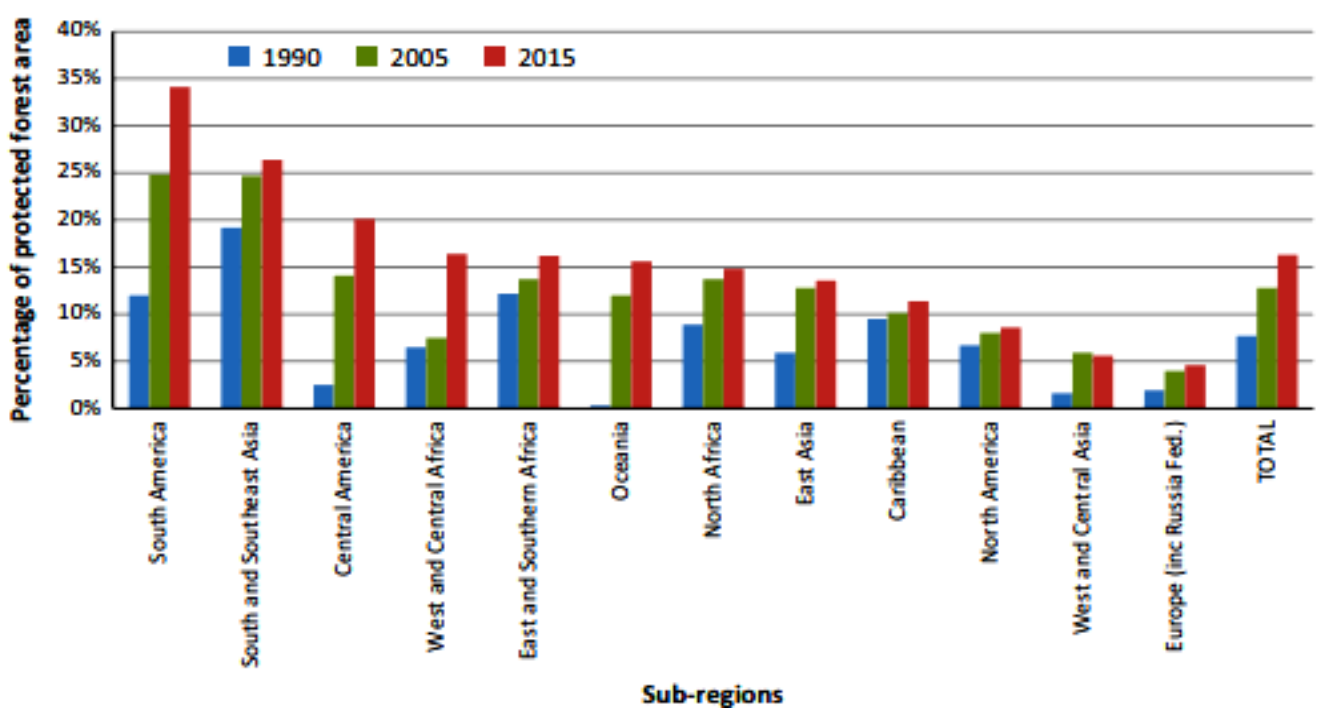

Fig. 1: Change in forest area in protected by sub-region and over time according country ${ }^{[22]}$

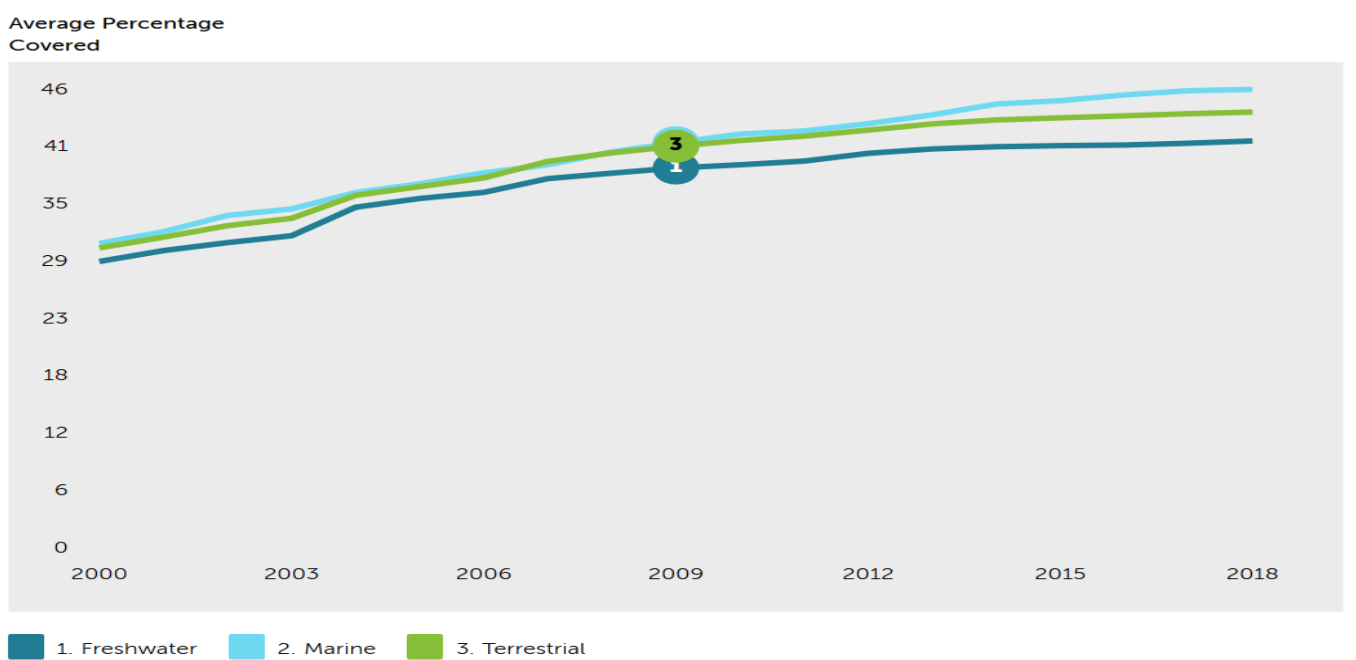

Fig. 2: Bird Life International, IUCN and UNEP-WCMC (2020), based on spatial overlap between polygons for Key Biodiversity Areas from the World Database of KBAs, compiled by Bird Life International and IUCN, and polygons for protected areas from the WDPA (March 2020)

Legend: Terrestrial KBAs: green, Freshwater KBAs: light blue, Marine KBAs (within EEZ): dark blue

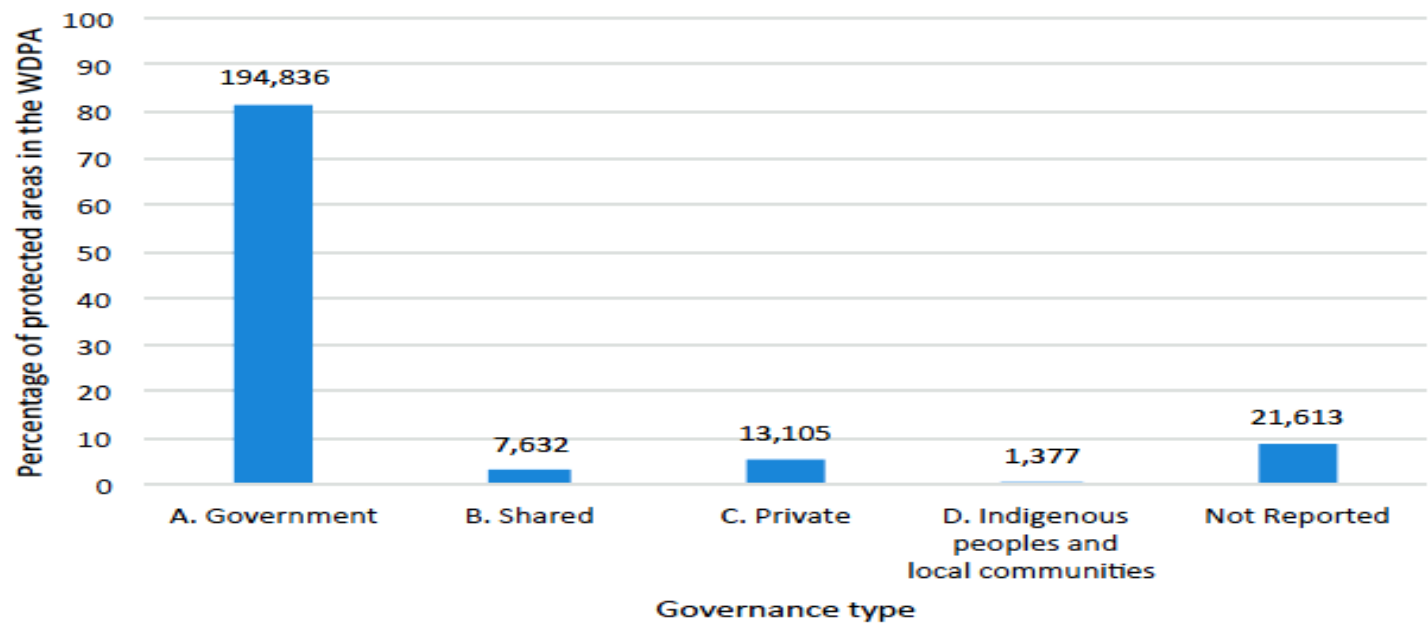

Fig. 3: Number and percentage of protected area reported in the WDPA under each IUCN governance type ${ }^{\text {[21] }}$ 
Rainforests of the Congo Basin, which covers Cameroon, Central African Republic, Democratic Republic of Congo, Equatorial Guinea, Gabon, and, following Amazon region, constitute world's second largest area of natural tropical rainforest in which the mandrills are the world's largest monkeys and can claim to be the most colorful of all mammal species live there, however not well protected and still illegally hunted for bush meat ${ }^{[24]}$. Furthermore, logging, mining and human population growth are placing extreme stress on the forest, causing habitat loss and hundreds of species are in danger of extinction ${ }^{[21]}$. Likewise, in Kenya, the forests have dwindled because large tracts of terrestrial and wetland ecosystems have been converted to farmland because of human actions, which threaten the existence of marine and terrestrial biodiversity. Though Ethiopia also possesses an estimated number of 6000 species of higher plants of which $10 \%$ are endemic, 284 species of wild mammals and 861 species of birds, and the number of reptile, fish, amphibian and arthropod species identified so far are 201, 200, 63 and 1,225, respectively, its biodiversity and forest resource is threatened with broadly linked to the limited governmental, institutional, and legal capacity; population growth; land degradation; weak management of protected areas; and deforestation ${ }^{225]}$, which are another attributes for global biodiversity loss.

If we fail to make efforts to solve these problems, our future generations will much less benefit from ecosystem services. Thus, to reduce the deterioration of ecosystems and biodiversity loss while responding to increasing demands, commitment of policy systems and practices should be must. Accordingly, the collective decisions of governments, publicly-funded bodies and local communities have resulted in rapid growth of national parks, nature reserves and protected wilderness areas throughout the world. This is because, as natural ecosystems shrink and fragment in many parts of the world, PAs are now expected to fulfill the needs of a growing range of stakeholders, primarily around protecting natural capital ${ }^{[26]}$.

The recognition of the Pas was efficient and costeffective to conserve threatened species and biodiversity ${ }^{[27]}$ and the agreement of formal targets for protection in international conventions ${ }^{[7]}$. The adoption of PAs as a core strategy to avert the current extinction crisis by protecting biological, ecological and evolutionary processes ${ }^{[27]}$ are critically important for the conservation of biodiversity ${ }^{[19]}$.

Of the studies reported, $82 \%$ showed that the chief threat to biodiversity is loss ofhabitat ${ }^{[28]}$, inside PAs compared to equivalent areas outside. In turn, $74 \%$ of species population showed more stability within protected areas than outside ${ }^{[28]}$.

Protected areas have been reported to have and to retain higher species richness and abundance than unprotected sites [29], similarly, forest PAs and community conservation initiatives generally lowered deforestation rates ${ }^{[30]}$ but still biodiversity losses or declines in species abundance continue to occur within protected lands in other sites. Recently, Gray et al. ${ }^{[29]}$ estimated that the global system of PAs is $41 \%$ effective at retaining species richness and 54\% effective at retaining local species abundance, particularly scientific evidence demonstrates that PAs successfully promote biodiversity conservation in marine and forest areas in particular ${ }^{[8]}$.

Protected areas are the cornerstone of biodiversity conservation ${ }^{[29,30]}$, where networks of PAs are large, connected, well managed, and distributed across diverse habitats, they sustain populations of threatened and functionally important species and ecosystems more effectively than other land uses ${ }^{[29]}$, it also plays an important role in climate-change mitigation and resilience. The extents to which biodiversity loss that exist in PAs are due to the potential lack of connectivity with other PAs, or with other natural habitats. However, Juffe-Bignoli et al. ${ }^{[8]}$ found that biodiversity losses in tropical PAs during the last 20-30 years were strongly determined by changes outside reserves such as deforestation, which may increase the isolation of PAs. As the principle of the International Union for Conservation of Nature (IUCN) includes explicit reference to conserving "nature with associated ecosystem services" [5], biodiversity has historically been the dominant goal of PA design, implementation, and management ${ }^{[34]}$. But a-now-days, a major shift underway toward broadening the goals of PAs from a dominant focus on biodiversity to one that also encompasses the provision of ecosystem services for human well-being ${ }^{[31]}$. Well-designed PAs can harmonize nature, improve ecosystem services, mitigate climate change, and enhance ecosystem resilience ${ }^{[33]}$. 
Generally, governing system of certain country has a role

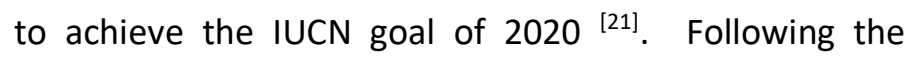
primary target and management method, the IUCN has classified PAs into six categories, including Strict Nature Reserve/Wilderness Areas, National Parks, Natural Monuments, Species Management Areas, Landscape PAs and PAs with Sustainable use of Natural Resources ${ }^{[21]}$. This classification standard has been adopted by many countries and is also used as the standard classification for consolidating statistics on PAs by the UN National Park and Nature Reserves program ${ }^{[1]}$, moreover, the categories are indicated in Table 1.

Table 1: The International Union for Conservation of Nature (IUCN) Protected Area Management Categories ${ }^{\text {[34] }}$

\begin{tabular}{|c|c|c|}
\hline No & Names & Descriptions \\
\hline Ib & Wilderness area & $\begin{array}{l}\text { Usually large unmodified or slightly modified areas, retaining their natural character and } \\
\text { influence, without permanent or significant human habitation, which are protected and } \\
\text { managed to preserve their natural condition. }\end{array}$ \\
\hline II & National park & $\begin{array}{l}\text { Large natural or near natural areas set aside to protect large-scale ecological processes, } \\
\text { along with the species and ecosystems characteristic of the area, which also provide a } \\
\text { foundation for environmentally and culturally compatible spiritual, scientific, educational, } \\
\text { recreational and visitor opportunities. }\end{array}$ \\
\hline III & $\begin{array}{l}\text { Natural } \\
\text { monument } \\
\text { or feature }\end{array}$ & $\begin{array}{l}\text { Areas set aside to protect a specific natural monument, which can be a landform, sea } \\
\text { mount, and submarine cavern, geological feature such as a cave or even a living feature } \\
\text { such as an ancient grove. }\end{array}$ \\
\hline
\end{tabular}

IV Habitat/species

Areas that aim to protect particular species or habitats and where management reflects this management priority. Many category IV protected areas will need regular, active interventions to address area the requirements of particular species or to maintain habitats, but this is not a requirement of the category.

V Protected An area where the interaction of people and nature over time has produced an area of landscape or seascape distinct character with significant ecological, biological, cultural and scenic value: and where safeguarding the integrity of this interaction is vital to protecting and sustaining the area and its associated nature conservation and other values.

VI Protected areas Areas, which conserve ecosystems and habitats, together with associated cultural values with sustainable and traditional natural resource management systems. They are generally large, with most use of natural of the area in a natural condition, where a proportion is under sustainable natural resource resources management and where low-level non-industrial use of natural resources compatible with nature conservation is seen as one of the main aims of the area. 
Anthropogenic activities resulted in extensive ecosystem degradation and made the loss of biodiversity in sever ways. But the recognition of the importance of biodiversity conservation and its linkages to global development issues was emphasized later in 1972 at the Stockholm conference on the human environment, where the complicated link between biodiversity conservation and human development was highlighted ${ }^{[35]}$. Moreover, the Sustainable Development Goals (SDGs) of 2030 Agenda for a better future for humanity free from poverty and hunger highlighted the importance of sustainable utilization of natural resource towards the attainment of the ambitious agenda of SDGs ${ }^{[36]}$.

Consequently, the dwindling species and degraded landscapes, seascapes and watershed loss of biodiversity reduce the quality of life for all, especially the poor. Key services that are lost as biodiversity disappears include the provision of clean water, food, materials, storm buffers, pollination of crops, and reduction of diseases such as malaria ${ }^{[33]}$.

Protected areas (parks/reserves) are used as an achievable goal to curb the problems that are recognized to protect species and stop habitat conversion. Protected area benefits extend to users at different scales, from local people who depend on particular species for their livelihood to nations that depend on abundant fresh water to the global community that depends on nature's capacity to regulate climate ${ }^{[8]}$ but protecting biodiversity and supporting livelihoods is a major challenge for sustainable management of PAs specially in third world countries like Africa.

The Millennium ecosystem assessment aroused great concerns about conservation for human welfare, which inherently links nature with society. Initially, the ecosystem services approach emphasizes that humans both depend on and benefit from PAs, which enhance current conservation efforts and attract more social and financial support [4]. Scholars like Tanyaradzwa [36] noticed that PAs are detrimental to livelihoods through denying communities access to traditionally used resources. BLI, LEIBL ${ }^{[18]}$, highlighted the importance of PAs in sustaining the flow of ecosystem services upon which humans depend for survival. These show that their restriction is used to conserve biological systems that will otherwise be depleted and degraded. On the other hand, PAs threaten peoples' rights and livelihoods due it allow access for some people but exclude others.
Controversies are complicated in two ways; first PAs are done into the founding stories that nations tell about themselves, secondly local consequences of Pasare highly contrary ${ }^{[37]}$. In other ways, PAs benefit peoples' livelihoods ${ }^{[38]}$; secure the rights of people to land and valuable natural resources that they lose [16]. Furthermore, the approaches of park management should be more inclusive of local communities in biodiversity conservation and then community empowering methods in conservation play a positive role [1]. Increasingly, parks are being designed to achieve multiple objectives and take the needs of stake-holders into account ${ }^{[5]}$. Not only this but also the inclusion of the communities' issue in park management had got weight to hinder loss of the biodiversity. To achieve the goals, conservation should emphasize on win-win solutions rather than conflict between conservation ${ }^{[39]}$.

Generally, the common role of PAs on human livelihoods is supporting and regulating services, cultural services, ecotourism benefits and political benefits and biodiversity conservation, which could be manifested in terms of "ecosystem services" and carbon sequestration the entire global community by abating climate change.

\section{Protected areas provide ecosystem services for human livelihoods}

Provisioning services- This is one of the positive impacts of PAs on ecosystem services for human welfare, and often used to identify and quantify the services provided by it, as they are mostly direct benefits with visible economic impacts. The reliance of local communities of forest resources has already been highlighted, and it could be suggested that one of the biggest benefits of PAs for local people is the protection of forest resources for future generations. Baral and Heinen ${ }^{[47]}$ argued that sustainable use of PAs can lead to more reliable resource base, whilst safeguarding the natural resources of a region for future use. For example, the Mexican community declared $29 \%$ of its forest as a biodiversity area and has begun reforestation in former agricultural plots ${ }^{[40]}$, the reserve in Colorado was created by the community for the preservation of cultural and natural resources ${ }^{[41]}$ resource extraction from protected areas, including timber and non-timber forest products has been available benefits ${ }^{[43]}$ in Uganda $44 \%$ of respondents reported that the protected area was positive because it conserves wildlife, and other benefits 
including the provision of water and grazing. Similarly, an attitudinal survey in three wildlife sanctuaries showed that $45 \%$ of residents were in favor of the protected area. In other conservation projects in the protected area reported an increase in fodder, fuelwood trees, forest cover, water resources and wildlife populations $[43,44]$

Supporting and Regulating services- Among the positive impacts of protected areas of human livelihoods, supporting and regulating services is also the crucial one which includes generating and maintaining soils, primary production, sustaining hydrological cycles, runoff control, prevention of soil erosion and storing and cycling essential nutrients. But the local communities may not recognize these services when their benefits accrue at the regional, national and global scales ${ }^{[48]}$.

In another area local communities recognize the benefits of PAs like in the Kerinci Seblat National Park, Indonesia, $94 \%, 88 \%$ and $66 \%$ farmers, thought that forest loss would result in flooding, soil erosion and attacks from insect pests respectively ${ }^{[45]}$ in the Annapurna community reserve, Nepal, reported improved water resources after an increase in forest cover in the reserve ${ }^{[43]}$.

Socio-cultural services- The cultural and social benefits of protected areas are an intrinsic aspect of their role in local livelihoods. The opportunities for the social benefits of protected areas can play a crucial role in maintaining cultural identity, preserving traditional landscapes and empowering local knowledge. Surveys taken in southwestern China indicate that the principal social benefits of the reserve are that of increased social stability and cultural identity ${ }^{[46]}$. These benefits may be less visible and tangible, but can be highly valued by local communities. The inclusion of local communities in planning stages and management decisions can help protected area managers to reach beyond socio-political factors ${ }^{[47,48]}$. Use of medicinal plants can be symbolically and culturally important, providing livelihood benefits through their social significance. Their value is not limited to that of a financial asset. Pyhala et al. ${ }^{[49]}$ argued that how non-timber forest products, particularly medicinal plants may be "held in special religious, nationalistic or ideological esteem". Various attempts were implemented at the community-based system of sustainable harvesting of medicinal plants alongside the facilitation of customary medicinal practices in local communities.

Protected areas positive impacts on human livelihoods through ecotourism benefits-Tourism in protected areas generates revenue directly and has therefore been supposed to be the ideal alternative income base on which to build sustainable conservation and developmental projects within it. Various studies documented local benefits either through the sale of goods and services to tourists or through the sharing of a portion of direct revenues such as entrance fees [43]. Moreover, Naidoo and Adamowicz ${ }^{[51]}$ argued that the tourism projects in protected areas need to embrace the market values of biodiversity attractions, including the tourist's willingness-to-pay in their pricing. This could substantially increase the revenue acquired and would be a significant source of funds for local communities involved in the projects. Many tourism projects yield significant non-financial benefits through the development of skills and increased access to information, credit and markets as well Cernea and Schmidt-Soltau ${ }^{[50]}$ in this way, ecotourism also benefits communities through nature-based ecotourism.

The challenges with the role of PA on ecotourism benefits to communities are, benefits generated by ecotourism are not always equitably shared within communities ${ }^{[41]}$, the success of protected area tourism is closely linked to participating community members in planning, designing, implementation, monitoring and evaluation stage.

Impacts of protected areas on human livelihoods through direct payments- Though, implementation of direct payment for private landowners for the conservation of ecosystems, their services is not common ${ }^{[42]}$. Advocates of direct payment schemes cite them as examples of 'win-win' conservation; directly valuing biodiversity, compensating local people for protecting area impacts, and thus efficiently delivering measurable conservation results. Historically, Hoopa reserve, California, USA between 1994 and 1998, local communities were paid by the Bureau of Indian Affairs for enhancing ecosystem services by restoring four main watersheds within the protected area, to reduce the sediment load flowing downstream ${ }^{[30]}$ sedimentation levels had been significantly reduced, and communities benefited financially, as well as from the enhanced 
environmental. The payments constitute about $30 \%$ of household incomes, and assistance for soil conservation and organic farming ${ }^{[52]}$, in Costa Rica rural residents ${ }^{[53]}$, paid for 10 years approximately \$35USD annually per hectare of forest protected, strengthened community association through the program.

Another most important direct payment strategy and the current burning agendas worldwide is the carbon sequestration, which offers increasing opportunities for payments for restoration and retention of forest carbon. Payment for carbon benefits increases the value of forests relative to other land uses. Although forests often provide needed goods, services and supplemental income, there are many situations in which sound forest management is currently not profitable. Carbon payments could be used to overcome barriers to maintain forests under sustainable management regimes.

Although the number of direct payment schemes is growing, they still cover only a tiny fraction of protected areas and forest communities. Like other development initiatives, direct payment schemes may negatively impact the livelihoods of those not involved in the scheme through increased land-use restrictions and loss of land tenure, and those excluded from these schemes may be the poorest members of the community who lack the capital for initial involvement and have few initial land-use rights ${ }^{[47,53]}$. To provide benefits, land tenure or equivalent rights must be established, and communities are involved in the decision making process [51]. Moreover, in protected forest CDM approach is one of the mechanisms, which are well-designed CDM forestry projects can contribute to better livelihoods by improving access and management of forest resources in ways that will benefit local people and contribute to greenhouse gas emission reductions, this CDM forestry projects can provide new sources of income and increased access to forest products and services, which will be resulted in encouraging the communities to take care of the protected forest.

Impacts of protected areas on human livelihoods through direct economical benefits-The role of PAs on human livelihoods, which are indicated in the previous section (1-3) directly or/indirectly, touches the role of PAs on economic issues for human wellbeing. Protected areas provide income through jobs and in some cases; they also provide direct income to communities through park fees ${ }^{[42]}$. Nowadays, the protected areas supposed to do far more than conserve biological diversity, but to provide economic benefits across multiple scales. Only recently have studies emerged showing the tangible economic benefits of protected areas, this is due even in global direction, in addition to conserving biological diversity, protected areas are to provide economic benefits at multiple scales, alleviate poverty, protect threatened cultures, and promote peace ${ }^{[49]}$.

One study of 41 reserves, covering approximately 1.5 million ha in Madagascar, found that the economic rate of return of the protected area system was $54 \%$. In South Africa, the working for water program is enhancing water security and improving the ecological integrity by eliminating invasive species, restoring degraded lands, and promoting sustainable use of natural resources ${ }^{[32]}$. It has employed over 42,000 people in less than four years. The study also confirmed other findings, e.g., there are often winners and losers from conservation, even among groups of the poor. In this example, 265,000 poor ricefarming households (average of 1.5 ha per household) benefited, as did the 25,000 urban households receiving potable water. But 50,000 shifting agriculturalists (also known as "slash-and-burn" farmers) were deprived of the land within the parks.

Threats of protected areas- Though during past few decades a remarkable amount of protected areas including reserve forest all over the world has brought and protected under different IUCN management categories and also the report of 2018 IUCN shows that as there is positive progress ${ }^{[54]}$. This, the remarkable physical expansion of protected areas during the past 25 years is a notable success for conservation, and it signals an international commitment to protecting biological diversity that is why protected areas are termed as the primary defense against biodiversity loss but extensive human activity within their boundaries can undermine this but nearly half of these legally PAs are heavily used usually illegally for agriculture, forest product extraction and illegal hunting of wild animals ${ }^{[55]}$, not only this but currently the research that was conducted by Kendall et al. ${ }^{[56]}$, revealed that one-third of global protected land is under intense human pressure which was done by using the most comprehensive global map of human pressure in which about 6 million square kilometers (32.8\%) of protected land is under intense human pressure. 
Because of natural resources in non-protected areas dwindles, the protected areas, as the sole remaining repositories of fuel wood and forage, etc. are becoming a focus for different illegal activities like poaching, illegal grazing, timber production and other human activities that affect the sustainability of these protected areas. Multinational approaches are crucial to conserving these shared areas, underscoring the need for cooperative management strategies among neighboring countries ${ }^{[21]}$. For instances, the river Nile constitutes key biodiversity corridor across the Sahara desert, but is heavily affected by human activities in its lower reaches, new irrigation schemes may further diminish water supplies in the lower Nile system and pose additional threats to its biodiversity and development projects like hydropower projects (e.g. Renaissance dam of Ethiopian hydropower project) will increase demands on the existing water resources and this, in turn, will exert additional pressure on the Nile basin's ecosystems and biodiversity.

Curbing the challenges of protected areas is a matter of survival for a human being. Threats to biodiversity are to be tackled effectively, especially in developing countries, where the degree of severity is high like Africa, it is essential to integrate biodiversity into national development planning and policies. Current trends reaffirm the need for an ecosystem approach to biodiversity conservation, its sustainable use and the fair and equitable sharing of its benefits. Other activities that can contribute to the halting of biodiversity loss include efforts to reduce the impacts of agriculture and extractive industries; the restoration of degraded ecosystems; the development of alternative livelihoods for local communities; and greater collaboration with the private sector, and also with non-governmental organizations working on conservation ${ }^{[19,21]}$. Generally, the $\mathrm{CBD}^{[19]}$ categorized the major threats to protected area into direct and indirect threats:

Direct threats- Includes, removing individual elements from PAs without alteration of the structure of the ecosystem, impoverishment of the ecology of the PAs (through encroachment, grazing, pollution, persistent poaching and illegal logging), conversion and degradation (removal of vegetation cover, construction of roads and mining), isolation (fragmenting adjacent lands) and valuing invasive species.

Indirect threats- Includes, inappropriate land allocation and land use decisions; unclear legal status of lands, waters and conflicts on it; weak and inconsistent enforcement of laws and regulations, rural poverty, unemployment, landlessness and finally, need of revenue by central or local governments are considered as an indirect threats.

Table 2: Economical benefits of Protected Areas

\begin{tabular}{lll}
\hline No & Protected area & Benefits
\end{tabular}

Lupande Game Management Area,
Zambia Forest Reserve 5,613 ha and
Game Management Area, 484,000
ha, IUCN Category VI

Maya Biosphere Reserve,

2. Guatemala $2,112,940$ ha, MAB

Tortuguero National Park,

3. Costa Rica 18,946 ha, IUCN Category II
The 50,000 residents earn annual revenues of US\$230,000 (representing $80 \%$ of the total revenue from two hunting concessions). The revenue is distributed in cash to both the local community and village projects, such as schools ${ }^{[11]}$

The Maya Biosphere Reserve in the Peten region of Guatemala generates annual income of approximately US\$47 million and employs 7000 people. The reserve is credited with almost doubling local family incomes ${ }^{[12]}$

While turtle eggs used to be sold on the black market, new ecotourism developments in 2003 generated US\$92,300 indirect income for the Gandoca community, who are situated $125 \mathrm{~km}$ from the Tortuguero National Park. This represents 6.8 times more income than that derived from selling turtle eggs. It was also estimated that each local tour guide in Tortuguero, on average, earned between 2 and 4 times the minimum wage (or US\$1,755-3,510) over a five month period. 
Cousin Island Special Marine

Reserve and Praslin National Park,

4. Seychelles 2 ha, IUCN Category la and 675 ha, IUCN Category II, respectively

\section{Muritz, Seen Park Landscape}

5. Protection Area, Germany, 30,000 ha, IUCN Category V
Overall about 359 jobs have been generated by ecotourism in this area. In addition, a local high school, clinic and improved water and waste treatment were set up using the revenue from the park ${ }^{[13]}$

Educational tourism is provided by three large travel agencies, all run by local Seychellois. Further, there are several locally-owned, small to medium-sized operators and charter boat businesses on neighboring Praslin Island. It is estimated that about USD600,000 is generated by these activities through direct and indirect revenues ${ }^{[14]}$

Tourism in the park generates over US\$17.7 million per year for the region, supporting an estimated 628 jobs ${ }^{[15]}$

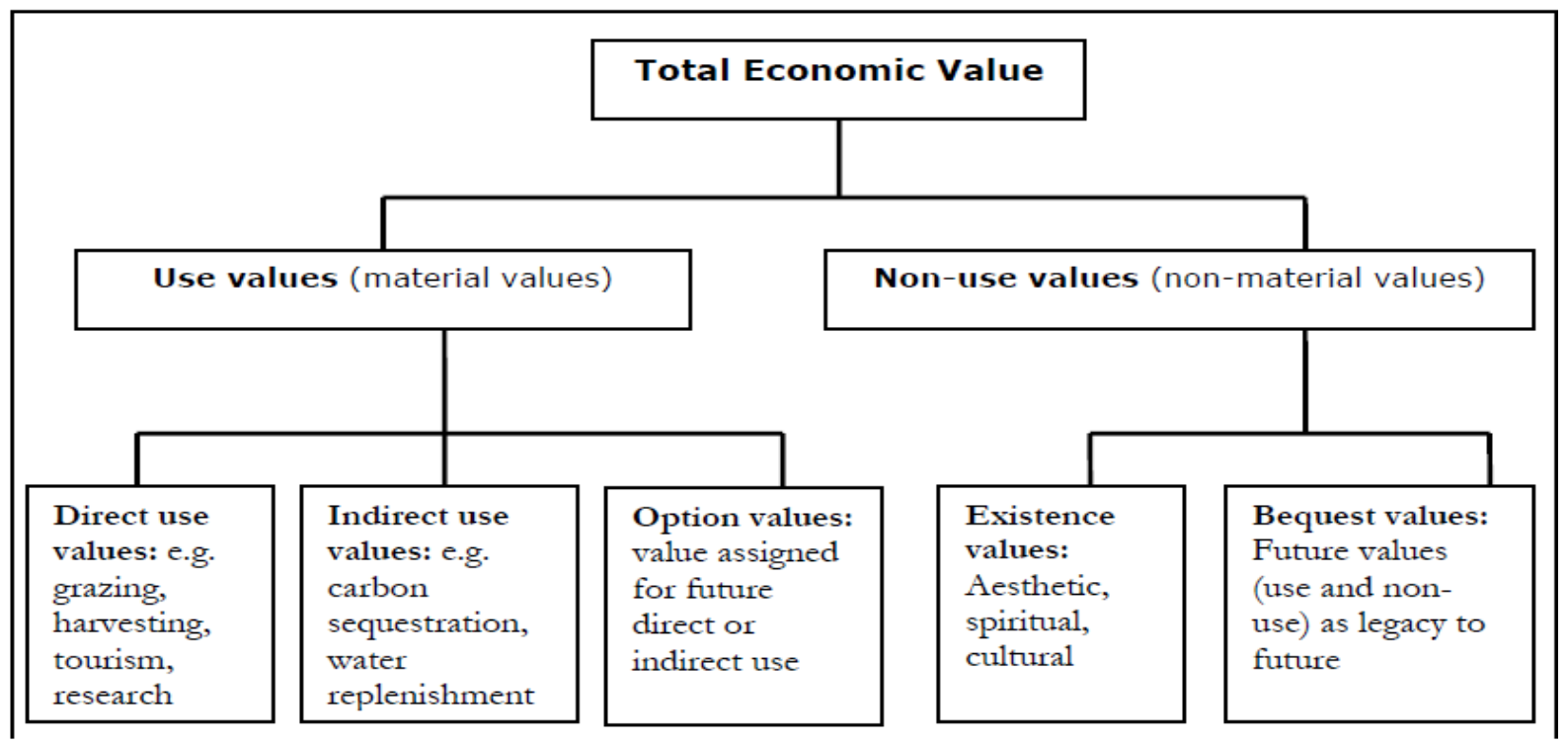

Fig. 2: Diagrammatically Display of the economical Value of Protected Area (source: IUCN, 1998)

\section{CONCLUSIONS}

Global trends show that the devastation on the earth is increased from time to time because of the severe degradation of an ecosystem and biodiversity loss. Human beings altered ecosystems in profound ways, through land-cover and land-use change, spread of invasive species, climate disruption, pollution and habitat disappearance in a persistent rate as whole. Protected area system is a newly emerged tactic that is supposed to restrain the threats of the biosphere and recognizing and managing means to achieve the long-term conservation of nature with the associated ecosystem.

Though during past few decades remarkable amount of PAs including reserve forest and wild life sanctuary all over the world has brought a positive impact, but nearly half of these legally PAs were heavily used for agriculture and illegal hunting, which should be tacked strategically.
The practice of safe guarding the maintenance of biodiversity and reducing the rate of biodiversity loss in PAs should be considered as an important backing for the future to attain a good result.

\section{ACKNOWLEDGMENTS}

The author would like to thank the Wolaita Sodo University for the provision of internet facility during the writing of this review paper; and the author also thanks those, who contributed in manuscript preparation in one way or the other.

\section{REFERENCES}

[1] Mengtian C, Li P, Shaoquan L. Analysis of the Network of Protected Areas in China Based on a Geographic Perspective: Current Status, Issues and Integration. Sustainabil, 2015; 7: 15617-31. 
[2] Pereira HM, Leadley PW, Proença V, Alkemade R, Scharlemann JPW, et al. 2 Scenarios to Global biodiversities in the 21 century. Sci., 2010; 330(6010): 1496-501.

[3] UN. Sustainable Development Goals: Upper Myanmar (Burma). J Env Conserv., 2016; 33(4): 34452.

[4] Fangli Wei, Shuai W, Bojie F, Linxiu Z, Chao F, et al. Balancing community livelihoods and biodiversity conservation of protected areas in East Africa. Current Opinion Environ Sustainabil., 2018; 33: 2633.

[5] Dudley N. Guidelines for Applying Protected Area Management Categories, IUCN, Gland, Switzerland, 2008; 1-143.

[6] Kelboro G, Stellmacher T. Contesting the National Park theorem: Governance and land use in NechSar National Park, Ethiopia. ZEF Working Paper, 2012; pp. 1-104.

[7] GermánBaldi, Marcos Texeira, Osvaldo A. Martin1, H. Ricardo Grau, Esteban G. Jobbágy. Opportunities drive the global distribution of protected areas. Peer J., 2017; 5: 2989.

[8] Juffe-Bignoli D, Burgess ND, Bingham H, Belle EMS, De Lima MG, Deguignet $M$, et al. 2014. Protected planet report 2014. Cambridge: UNEPWCMC.

[9] Lovejoy TE. Protected areas: a prism for a changing world. J Trends Ecol., 2006.

[10]Adams WM, Hutton J. People, parks and poverty: political ecology and biodiversity conservation. Conservation and Society, 2007; 5(2): 147-83.

[11]Joppa LN, Loarie SR, Pimm SL. On the protection of protected areas. Proc Natl Acad Sci., USA, 2008; 105: 6673-78.

[12]Walther BA. A review of recent ecological changes in the Sahel, with particular reference to land-use change, plants, birds and mammals. Afr J Ecol., 2016; 54: 268-80.

[13]Derera K. Ethiopia: Changes from "People out Approach" Protected Area Management to Participatory Protected Area Management? Insight from Ethiopian Protected Areas, Research gate available at 2017.

[14]Galvin M, Haller T (eds). People, protected areas and global change: Participatory conservation in Latin America, Africa, Asia and Europe. Perspectives of the Swiss National Centre of Competence in Research
(NCCR) North-South, University of Bern. 3. Geographica Bernensia, Bern, 2008.

[15]Bruno P, Maria P. The History of the Establishment and Management Philosophies of the Portuguese Protected Areas: Combining Written Records and Oral History. Environ. Manag., 2012.

[16]Child B. (Ed.). Parks in Transition. IUCN (World Conservation Union), Earthscan. London, 2004.

[17]Phillips A. Turning ideas on their heads: the new paradigm for protected areas. The George Wright FORUM, 20(2):8-32.planet: a global history. Proceedings of the National Academy of Sciences of the United products in Peruvian Amazonia. Ecosyst., 2003; 9: 1328-41.

[18]Mose I, Wiexlbaumer N. A new paradigm for protected areas in Europe In: Mose I (ed) Protected areas and regional development in Europe towards a new model for the $21^{\text {st }}$ century. Ashgate Publishing, Derbyshire, 2007.

[19]CBD Secretariat. Updated status of Aichi Biodiversity Target 11. Note by the Executive Secretary. CBD, 2018.

[20]Keenan RJ, Reams GA, Achard F, de Freitas JV, Grainger $A$, et al. Dynamics of global forest area: results from the FAO global forest resources assessment. For. Ecol. Manag., 2015; 352: 9-20.

[21]IUCN and UNEP-WCMC. The World Database on Protected Areas (WDPA): UNEP-WCMC, Cambridge, UK, 2014.

[22]Food and Agricultural Organization of the United Nations (FAO).Global Forest Resources Assessment. Rome, Italy, 2010; 163: 378.

[23] Global Biodiversity Strategy Office/GBSO. The Third National Biodiversity Strategy of Japan, 2008;

[24]FAO. The State of Forests in the Amazon Basin, Congo Basin and Southeast Asia: A report prepared for the Summit of the Three Rainforest Basins Brazzaville, Republic of Congo, 2010.

[25]Ethiopian Biodiversity Institute/EBI. Fifth National Report to the Convention on Bio. Diversity, 2014.

[26]Watson JEM, Dudley N, Segan DB, Hockings M. The performance and potential of protected areas. Nature, 2014; 515: 67-73.

[27]Butchart SHM, Scharlemann JPW, Evans MI. Protecting important sites for biodiversity contributes to meeting global conservation targets. Plos, 2012. 
[28]Kevin JG, Sarah FJ, Lisette CS, Gabriela CP. The Ecological Performance of Protected Areas. Annu. Rev. Ecol. Evol. Syst., 2008; 39: 93-113.

[29]Gray CL, Hill SLL, Newbold T, Hudson LN, Borger L, et al. Local biodiversity is higher inside than outside terrestrial protected areas worldwide. Nat. Commun., 2016; 7: 12306.

[30]Geldmann J, Barnes M, Coad L, Craigie I, Hockings M, et al. Effectiveness of terrestrial protected areas in reducing biodiversity and habitat loss. Collaboration for Environmental Evidence, 2013.

[31]Coetzee BWT, Gaston KJ, Chown SL. Local scale comparisons of biodiversity as a test for global protected area ecological performance: A metaanalysis, PLOS, 2014.

[32] Weihua $X, Y i X$, Jingjing $Z, W u ~ Y, ~ L u ~ Z$, et al. Strengthening protected areas for biodiversity and ecosystem services in China. J. Ecol. Sustain. Sci., 2017; 114(7): 1601-06.

[33]Morales-Hidalgo D, Sonja N. Oswalt E. Somanathan.Status and trends in global primary forest, protected areas, and areas designated for conservation of biodiversity from the Global Forest Resources Assessment. Forest Ecol. Manag., 2015; 352: 68-77.

[34]Nigel Dudley and Sue Stolton (eds). Defining protected areas: an international conference in Almeria, Spain. Gland, Switzerland: IUCN. 220 pp objectives. ProcNatl. Acad. Sci. USA 2008; 112(35): 11132-37.

[35]Nelson F. politics of natural resource governance in Africa, in Community Rights, Conservation and Contested Land: the Politics of Natural Resource Governance in Africa, F. Nelson, Ed, Earth scan, London, UK, 2010.

[36]Tanyaradzwa C. More than Just Story Telling: A Review of Biodiversity Conservation and Utilisation From Precolonial To Postcolonial Zimbabwe. Trends Ecol. Evol., 2018; 19(5): 231-37.

[37]Brockington D, Wilkie D. Protected areas and poverty. Phil. Trans. R. Soc., 2015; 370.

[38]Andam KS, Ferraro PJ, Sims KRE, Healy A, Holland MB. Protected areas reduced poverty in Costa Rica and Thailand. Proc. Natl Acad. Sci. USA, 2010; 107: 9996-10.

[39]Sunderland TCH, Ehringhaus C, Campbell BM. Conservation and development in tropical forest landscapes: a time to face the trade-offs. Environ. Conserv., 2007; 34(4): 276-79.

[40]Barton-Bray D, Merino-Perez L, Negeros-Castillo P, Segura-Warnholtz TR, West $P$, et al. Parks and peoples: the social impact of protected areas. Annual Review of Anthropol., 2006; 35: 251-77.

[41] Hansen MC, Stehman SV, Potapov PV. Quantification of global forest cover loss. Proc. Natl. Acad. Sci. USA, 2010; 107: 8650-55.

[42] Upton RL, Hulme D. Are poverty and protected areas establishment linked at a national scale?. Oryx, 2008; 42(1): 19-25.

[43] Bajracharya SB, Furley PA, Newton AC. Impacts of Community-based Conservation on Local Co mmunities in the Annapurna Conservation Area, Nepal. Biodiversity and Conservation, 2006; 15(8): 2765-86.

[44]Sohn J. Protecting the Peruvian Amazon and its People from the Risks of Oil and Gas, 2007.

[45]Linkie M, Dinata $Y$, Nofrianto A, Leader-Williams N. Patterns and perceptions, 2007.

[46] Lü Y, Chen L, Fu B, Liu S. A framework for evaluating the effectiveness, 2003.

[47]Baral N, Heinen JT. Resources use, conservation attitudes, management intervention and parkpeople relations in the Western Terai landscape of Nepal. Environmenta, 2007; 134: (1): 64-72

[48] Kideghesho JR, Roskat E, Kaltenborn BP. Factors influencing conservation attitudes of local people in Western Serengeti, Tanzania. Biodivers. Conserv., 2007; 16(7): 2213-30.

[49] Pyhala A, Brown K, Adger WN. Implications of livelihood dependence on non-timber, 2006.

[50]Cernea MM, Schmidt-Soltau K. Poverty Risks and National Parks: Policy Issues inchange mitigation. Proc. Natl. Acad. Sci. USA, 2006; 107(24): 10821-26.

[51]Naidoo R, Adamowicz WL. Economic benefits of biodiversity exceed costs of conservation at an African rainforest reserve. Proceedings of the National Academy of Sciences of the USA, 2005; 102(46): 16712-16.

[52] Echavarria M, Vogel J, Albán M, Meneses F. Impacts of Payments for Watershed, 2004;

[53] Grieg-Gran M, Porras I, Wunder S. How can market mechanisms for forest environmental services help the poor? Preliminary lessons from Latin America. World Dev., 2005; 33(9): 1511-27. 
[54]Mukul SA. Bridging livelihoods and forest conservation in protected areas: Exploring the role and scope of non-timber forest products. Field experience from Satchari National Park, Habiganj, Bangladesh. BSc. Dissertation. Shahjalal University of Science and Technology, Sylhet, Bangladesh, 2007; pp. 95.
[55]McNeely JA. Friends for Life: New partners in support of protected areas. IUCN, Gland Switzerland and Cambridge, UK, 2005; pp. 232.

[56] Kendall RJ, Oscar V, Richard AF, James RA, Sean LM, et al. One-third of global protected land is under intense human pressure. Sci., 2018; 360: 788-91. doi: 10.1126/science.aap9565. 